\title{
The Correlation Between Student Perceptions of the Use of E- Modules with Students' Basic Science Process Skills
}

\author{
Darmaji $^{1 *}$, Dwi Agus Kurniawan ${ }^{2}$, Astalini $^{3}$, Febrina Rosa Winda ${ }^{4}$, Heldalia ${ }^{5}$, Lia \\ Kartina ${ }^{6}$ \\ ${ }^{12345}$ Department of Physics Education, Faculty of Teacher Training and Education \\ Universitas Jambi, Jambi, Indonesia \\ e-mail: darmaji@unja.ac.id ${ }^{1}$, dwiagus.k@unja.ac.id², astalinizakir@unja.ac.id³,$\underline{\text { febrinarosawinda@gmail.com4 }}$, \\ amakoheldalia@gmail.com ${ }^{5}$, liakartina98@gmail.com ${ }^{6}$
}

\begin{abstract}
This study aims to analyze the correlation of students' perceptions of e-module toward students' basic science process skills. The subject of the study were second semester students of Department of Physics Education in Universitas Jambi. This research used a mixed-method research with data collection instruments consisting of student perception questionnaire, observation sheet of students' science process skills, and also interviews. From the results of data analysis, students' perceptions were in the good category with an average of 74.95, and the basic science process skills of students were also in the good category with an average of 69.08. Based on the correlation test conducted there is a significant relationship between the level of student perception of e-module with students' basic science process skills using Pearson correlation values 0,927, and Sig. (2-tailed) 0.00 at a significance of $1 \%$.
\end{abstract}

Keywords: Science Process Skills, Physics Practicum

\section{Introduction}

Science process skills are skills that are needed in practical activities (Rahmawati et al., 2018; Vyas \& Nirban, 2014). With good knowledge and skills will follow the times. As we saw in the era of the 4.0 revolution, various technologies have developed very rapidly. T he development of science and technology has led to a process of change in all aspects of life, Including the world of education (Darmaji, Astalini, et al., 2019). Today's education requires the use of technology to develop and improve human resource improvement competencies. because now is the era of industrial renewal lament 4.0 (Astalini, Kurniawan, et al., 2019). The use of technology in learning activities in this era of revolution 4.0 is everywhere, one of which is smartphone -based learning media with the development of technology which is used as learning media to facilitate learning activities.

One way to improve the quality of education is by utilizing information technology to improve the quality of learning activities. In the last few decades, information and communication technology has developed rapidly and computer usage has become more widespread (Vyas \& Nirban, 2014). Media are in use in a process of learning is already familiar, namely smartphones. Smartphone is the device that allows learners to complete various problems, triggers the possibility of smart phone integration in the lecture $(A . N$. Yunita et al., 2018). Affordability is one of the key factors that customers consider in choosing mobile services aside from ease-of-use and usefulness (Jambulingam, 2013). Learning that takes advantage of mobility from mobile devices such as smartphones refers to the term mobile learning .

Mobile learning is learning that is done when students are not predetermined fixed location (Oyelere et al., 2016; Zidoun et al., 2016). Mobile learning is learning that can be simplified by using mobile devices (Ali \& Arsyad, 2016). Mobile learning carries the meaning of learning at anytime and anywhere through the use of mobile devices and the wireless Internet (Ali \& Arsyad, 2016; Saifuddin, 2018). Then using mobile learning in basic physics II will be more effective and can improve student skills. In addition you can improve

\footnotetext{
${ }^{*}$ Corresponding author.

Received 28 August 2020; Accepted 18 September 2020; Available online 01 December 2020 (c) 2020 JPI. All Rights Reserved
} 
the education system in a learning, mobile learning can also be used as media in assessment called cellular learning assessment (Darmaji et al., 2019). Also, cellular the device is used to calculate scores and manage standard assessments (Stathopoulou et al., 2018). The positive impact is the ease in learning and also variations in teaching which will have an impact on student learning outcomes. The mobility features of mobile devices make them a potential tool to motivate students as they progress in improving their grades (Ziden et al., 2017). Mobile devices enable learners to gain immediate access to data as mobile devices are place-independent (Ismail \& M.Idrus, 2009). One form of contribution to the use of technology in practicum is the use of an electronic practicum guide (e-module) which can be accessed by using a variety of tools applied in Physics practicum.

Physics practicum is one of the obligations for students majoring in mathematics and science education which aims to prove the truth of theories, principles, concepts and laws in physics (Astalini, Darmaji, et al., 2019). In order for the practicum to be carried out properly, a practicum guide is needed. The practicum module is a module compiled to assist in the implementation of practicum which contains the experimental title, objectives, theoretical basis, tools and materials, and questions that lead to goals following the rules of scientific writing (Darmaji, Astalini, et al., 2019). A good guide is a guide that is easy for students to understand. The e-module is one of the solutions in the enrichment of mastery of the material by students (Bulte et al., 2006). A practicum activity requires science process skills that students have, such as formulating hypotheses; formulate problems; operational definitions of variables; identify variables and analyze data; and draw conclusions so that you get knowledge in achieving learning competencies (Misbah et al., 2018). Sains process skills can be developed with practical science guided by a guide who is able to train lab science process skills of students (Darmaji, Kurniawan, \& Suryani, 2019). practicum in physics course activities will be supported by the perceptions of physics students regarding the activities or concepts learned in practicum activities

Perception is part of the process of entering messages or information into the human brain. Melauli perception, humans continuously make contact with their environment. This relationship is carried out with the senses of sight, hearing, touch, taste and smell (Asrial et al., 2020). Perception can be divided into two, namely, positive perception and negative perception (Amin et al., 2019). Positive perception is an individual's assessment of an object or information with a positive view or as expected from the object being perceived. Meanwhile, negative perceptions are the views of individuals who are opposite from the expectations of the object being perceived or the rules that are enforced (Triyono, 2018). In physics learning activities, students often create negative perceptions of learning because physics is a difficult material.

Perception analysis in physics education students is needed in increasing student interest in the material being taught (Y. Yunita et al., 2019). To create a positive perception in the learning process, it is usually added with learning media. This learning media does not only apply to concept understanding but to the physics process by holding practicum activities (Darmaji, Kurniawan, Astalini, \& Nasih, 2019). Usually practicum activities are only supported by hardcopy or printed practicum guides. The form of printed guides makes it difficult for students to do practical activities because they have to flip through the paper so that activities in practicum are hampered (Nasih et al., 2019). So a practical practicum guide is needed, one of which is in digital form or a website.

Mobile learning is a term commonly used for learning media that utilizes technology (Pathoni et al., 2017). Mobile learning is software that provides many benefits, namely, flexibility and freedom in learning as well as skills in discussion (Darmaji et al., 2019). It is very certain that by using technology as a supporting medium for learning, this can be applied in the form of a practicum e module. $E$ module is one of the changes in physics student practicum activities. Students find it easier to use practicum guides because of their easier nature (Nugraheni \& Dina, 2017). The ease of users in using and utilizing a technology can say that the technology is successful (Amalia \& Brata, 2018). A technology acceptance can be seen through the perceptions given by the respondent. Perception is closely related to the five senses because we can give perception to an object, because we 
see, hear or feel that object. The connection between these five senses is also related to the process of practicum activities. The process of this practicum activity is usually with student science process skills.

Science process skills are one of the important aspects in research activities that are always improved for strengthening in physics practicum activities (Julius Zai, 2019). Science process skills are usually supported by various learning media, one of which is a practicum guide. Practicum guide as a reference for students in carrying out physics practicum activities that are adjusted to indicators of science process skills (Rohman \& Lusiyana, 2017). However, there are no studies that use students' perceptions of using e module guides to improve science process skills. Usually science process skills are enhanced by a practicum process that applies a learning model that opens student perceptions (Piliang, 2019).

This study aims to analyze the relationship of students' perceptions in using a digitalbased practicum guide (e module) with the science process skills of physics education students for Melde material.

\section{Method}

This study was conducted to investigate the relationship between students 'perceptions of e-module and students' science process skills in the Melde experiment. The subjects in this study were 50 physics education students taking Basic Physics II courses. Qualitative data from this study were obtained through interviews where the respondents consisted of students and teachers. The quantitative data collection instrument in this study was an observation sheet of science process skills consisting of 6 indicators of basic science process skills. In the process of taking it, the observer will observe and fill in the observation sheet. The observation sheet consisted of 22 statements whose assessments used four Likert scales, namely very good with a score of 4 , good with a score of 3 , not good with a score of 2, and very not good with a score of 1.

To determine students' perceptions of the e-module, researchers used a questionnaire consisting of 20 statements using 5 Likert scales, namely very good with a score of 5 , good with a score of 4 , enough with a score of 3 , not good with a score of 2 , and very not good with a score of 1 . As for qualitative data obtained through interviews with several students as representatives. After that the quantitative data from the science process skills observation sheet and student perception questionnaire will be processed to determine whether there is an influence or no influence between the two variables. Analysis of the data used is to do a correlation test that was previously performed prerequisite test analysis, namely the normality test and linearity test. Data testing here is carried out with the help of the SPSS application.

After data from all respondents were collected, the data were analyzed to determine whether there was an effect of student perceptions on the e-module with students' science process skills. As for doing so, the prerequisite tests must be carried out first, namely the normality test and the linearity test. Furthermore, if all the requirements for the analysis prerequisite test have been met, the correlation test is carried out. The correlation test is used to determine the degree of influence between the independent variable and the dependent variable. The correlation test used in this research is the Pearson Product Moment (PPM) correlation. In this study, the data were processed with the help of IBM SPSS Statistics 25.

\section{Results and Discussion Results}

The results of the basic science process skills data of students in the Melde practicum can be seen in table 1 and table 2 . 
Table 1. Description of the students' science process skills on Melde's Experiment

\begin{tabular}{ccccccccc}
\hline Interval & Category & $\mathbf{f}$ & $\%$ & Mean & Me & Mo & Max & Min \\
\hline $22-38,5$ & STB & 0 & $0 \%$ & & & & & \\
$38,51-55$ & TB & 4 & $11,1 \%$ & 69,08 & 69,00 & 69,00 & 86,00 & 54,00 \\
$55,1-71,5$ & B & 21 & $58,3 \%$ & & & & & \\
$71,51-88$ & SB & 11 & $30,6 \%$ & & & & & \\
Total & & 36 & $100 \%$ & & & & \\
\hline
\end{tabular}

Based on table 1 regarding the statistical description of students' basic science process skills in the Melde practicum shows that for the acquisition of a score of 36 respondents it was found that most students have good science process skills. This is seen from $58.3 \%$ of 36 students in the good category, while $30.6 \%$ or 11 students are in the very good category. As for the category of not good in the second-largest which is $11.1 \%$ or equivalent to 4 students, and $0 \%$ is in the category that is not very good. For the average overall student results obtained by 69.08 with a median of 69.00 and 69.00 mode. For the largest value obtained is 86.00 and the lowest value is 54.00 .

Tabel 2. the level of students mastering science process skills in the Melde experiment

\begin{tabular}{ccccc}
\hline \multirow{2}{*}{ Indicator } & \multicolumn{4}{c}{ Kategori } \\
\cline { 2 - 5 } & $\begin{array}{c}\text { Very Not } \\
\text { Good (\%) }\end{array}$ & $\begin{array}{c}\text { Not Good } \\
(\%)\end{array}$ & Good (\%) & $\begin{array}{c}\text { Very } \\
\text { Good (\%) }\end{array}$ \\
\hline Observing & 0,00 & 5,5 & 41,6 & 52,7 \\
Classifying & 8,3 & 13,8 & 47.2 & 30,5 \\
Measuring & 0,00 & 8,3 & 41,7 & 50,0 \\
Predicting & 5,5 & 8,3 & 58,3 & 27,8 \\
Comunicating & 2,7 & 13,8 & 27,7 & 55,5 \\
Inferring & 0,00 & 11,1 & 30,6 & 58,3 \\
\hline
\end{tabular}

Based on table 2 shows the results of students' science process skills reviewed each indicator of basic science process skills, namely observation, classification, measuring, prediction, communication, and concluding. Of all the indicators, the indicator concluded getting the highest score with $58.3 \%$ of students in very good category. After that, it was followed by a communication indicator that is $55.5 \%$ of students in the very good category and continued by observing and measuring indicators which respectively obtained a percentage of $52.7 \%$ and $50.0 \%$. Meanwhile the prediction indicator is in the good category with a percentage of $58.3 \%$. The same thing also happened to the classification indicators that are in the good category with a percentage of $47.2 \%$.

Tabel 3. Description of perceptions of students on basic physics practicum's E-module Guidebook

\begin{tabular}{cccccccc}
\hline \multicolumn{2}{c}{ Classification } & & & Mean & Median & Min & Max \\
\cline { 1 - 4 } Interval & Category & f & $\%$ & & & & \\
\hline $20,0-36,0$ & STB & 0 & $0 \%$ & & & & \\
$36,1-52,0$ & TB & 0 & $0 \%$ & & & \\
$52,1-68,0$ & C & 4 & $11.1 \%$ & 74,95 & 74,5 & 88,0 & 63,0 \\
$68,1-84,0$ & B & 29 & $80.6 \%$ & & & & \\
$84,1-100,0$ & SB & 3 & $8.3 \%$ & & & & \\
\hline
\end{tabular}

Based on table 3 regarding the statistical description of students 'critical thinking skills in students' perceptions of e-modules related to the Melde experiment it was found that most students had good perceptions of e-modules. This is seen from $80.6 \%$ of 36 students in the 
good category and $8.3 \%$ or equivalent to 3 students in the very good category. As for the enough category which is $11.1 \%$ or equivalent to 4 students. For the category of not good and very not good at $0 \%$. For the average of all students, the results were 74.95 with a median of 74.5. For the largest value obtained is 88.00 and the lowest value is 63.00 .

To test the correlation, the normality test and linearity test are performed first. the results can be seen in table 4 , table 5 , and table 6 .

Table 4. The result of normality test

\begin{tabular}{lccc}
\hline & \multicolumn{3}{c}{ Kolmogrov-Smirnov } \\
\cline { 2 - 4 } & Statistic & df & Sig. \\
\hline SPS & .109 & 36 & .200 \\
Perception & .117 & 36 & .200 \\
\hline
\end{tabular}

Based on the table data above, it can be seen in the Kolmogorov-Smirnov table section. For students' basic science process skills, the Sig value is 0.200 , which means that the Sig value is $>0.05$, so it can be said that the data is normally distributed. As for the data on student perceptions of the e-module, the Sig value is 0.200 , which means that the Sig value is $>0.05$ so that it can be said that the data is normally distributed.

Table 5. The result of linearity test

\begin{tabular}{|c|c|c|c|c|c|c|c|}
\hline & & & $\begin{array}{l}\text { Sum of } \\
\text { Squares }\end{array}$ & df & $\begin{array}{l}\text { Mean } \\
\text { Square }\end{array}$ & $\mathbf{F}$ & Sig. \\
\hline sps * & Between & (Combined) & 1680.556 & 15 & 112.037 & 17.725 & .000 \\
\hline \multirow[t]{4}{*}{ perception } & Groups & Linearity & 1551.681 & 1 & 1551.681 & 245.487 & .000 \\
\hline & & $\begin{array}{l}\text { Deviation } \\
\text { from } \\
\text { Linearity }\end{array}$ & 128.875 & 14 & 9.205 & 1.456 & .216 \\
\hline & \multicolumn{2}{|c|}{ Within Groups } & 126.417 & 20 & 6.321 & & \\
\hline & \multicolumn{2}{|l|}{ Total } & 1806.972 & 35 & & & \\
\hline
\end{tabular}

If viewed from the significance (sig), based on the output above, the deviation of linearity sig is obtained. is 0.216 which is greater than 0.05 . So it can be concluded that there is a significant linear relationship between the variable student perceptions of the use of the e-module with the variable student basic science process skills. If it is reviewed based on the $F$ value, then from the output above, the calculated $F$ value is 1.456 small from the $F$ table value of 2.22. Because the calculated $F$ value is smaller than the $F$ table value, it can be concluded that there is a significant linear relationship between the student's perception variable on the use of the e-module and the student's science processing skills variable.

Table 6 The result of correlation test

Pearson Correlation $.927^{* *}$

Sig. (2-tailed) .000

**. Correlation is significant at the 0.01 level (2-tailed).

Based on table 6, the Sig (2-tailed) score of 0,000 is obtained at a significant level of 0.01 . In this case $0,000<0.05$ which means there is a very strong relationship between science process skills. As for the calculated r-value (Pearson correlation), the known r-value is 0.927 while the $r$-table is 0.413 . Because $0.769>0.413$ there is a significant relationship.

\section{Discussion}

Based on the data the researchers obtained, it was found that most or as many as $80.6 \%$ of students had a good perception of the use of web-based e-modules as a guide in 
practicum. The results of interviews with students explained that the use of web-based emodules was more effective and efficient. Students explained that the advantages of the emodule are in the ease of accessing them because they can be accessed directly using any device without the need to have a special application. The use of electronic environments in educational technology started fairly recent to make the learning process easier and increase the accessibility of learning and teaching (Seraj \& Wong, 2014). The use of e-module can contain unlimited information so that the steps given to students in carrying out practicum are really detailed.

Students also explained that the e-module is also easy to organize because it has been integrated into the web that can be accessed directly so that the guide is left behind as often happens when using a guide in printed form which ensures the effectiveness of the practicum course. As the mobile device is an individual device, a sense of responsibility and self-managing of learning is supported by using m-learning (Coursaris \& Hassanein, 2002). In addition, the use of the e-module minimizes the use of paper so that it is also more economical. New operating systems, very useful applications to use them daily, and even with the reduction of costs due to the arrival of new competitors has generated an increase in users (Damyanov \& Tsankov, 2018) The implementation of practicum activities can be carried out well if it is equipped with a guideline, one of which is a practicum guide module (Wahyudi \& Lestari, 2019).

Student perceptions that are good about the use of this practicum module are also because students feel motivated after using the e-module. By including technology in the learning process, students will become more motivated in learning (Asrial et al., 2019). Content that can be enjoyed more easily and whatever is available can use learning resources effectively. Motivation is important in determining how many students learn from learning activities or how much to absorb the information presented to them (Anjani et al., 2016). The results of interviews with students showed that by using the e-module, students became more motivated because the forms of learning became more varied so that they attracted interest in learning. This is in line with the research of (Syahrial et al., 2019) that the use of an ethno constructivist e-module can motivate students in learning activities so that students are more interested in learning. This is inseparable from the appearance of the emodule which is more attractive than the practical guide in printed form. Printed sheets tend to be informative and unattractive that cannot display, sound, video, animation, and images that can provide a clear explanation of the concept of being conveyed (Haryanto et al., 2020).

The results of interviews with students also explained that students agreed to use technology in learning because more and more new things could be learned. The results of research conducted by (Rojas-Osorio \& Alvarez-Risco, 2019) show that the behavioral intention to keep using a smartphone was significantly influenced by perceived ease of use, perceived usefulness, and attitude toward keeping using a smartphone. In addition, students also explained that the use of e-modules is more in line with the times where currently students tend to use smartphones as a device to access information (mobile learning). Mobile-based learning has recently become an important modality used in e-learning environments. In the classroom, the use of mobile devices has been found to contribute to the learning experience and engage students during lectures. Students perceive the tablet PC to be effective in improving their learning environment (Foti \& Mendez, 2014).

Perception is the experience of objects, events, or relationships obtained by gathering information and interpreting messages (Simamora, 2014). Perception is a person's tendency in the relative realm so that each individual will have a different perception. This is supported by the results of research by (Nugraha, 2015) that the perception that each student has in the scope of the learning process is different so that it will also affect the differences in learning outcomes of each individual. The tendency of students to accept or reject learning depends on student interest in learning to be learned. This interest is influenced by the perceptions that students have. The same thing was expressed by (Marhento, 2015) that perception is the tendency in a subject to accept or reject a subject as a valuable subject. Based on the data the researchers obtained, it was found that $80.6 \%$ of students had a good 
perception of the use of web-based e-modules as a guide in practicum with the reasons that had been described in the interview. The positive perception of this e-module is due to its ease of access, effectiveness, and efficiency.

Practicum is the best learning method for developing science process skills because learning with practicum can provide opportunities for students to act directly in an activity that proves a theory (Salamah \& Mursal, 2017). Through the practicum, students are given the opportunity to experience themselves or do it themselves, follow a process, observe an object, analyze, prove and draw their own conclusions about an object, state, or process (Margunayasa \& Riastini, 2014). Practicum as a forum for developing science process skills, then the factors that influence the course of the practicum must be considered, one of which is the practical guide book. Practical activities in order to run according to the goals to be achieved require adequate facilities and infrastructure such as laboratories and relevant teaching materials or practical manuals (Sumarti et al., 2018). One of the efforts to develop student science process skills is through the use of guides practicum based on science process skills (Darmaji et al., 2018). This is in line with (Santiani, 2013) a practicum guide as a source of learning in practicum activities, which is a guide for students in developing science process skills.

The results of data analysis that have been carried out indicate that there is a significant positive relationship between student perceptions of e-module and students' science process skills. This is indicated by the Pearson correlation score of 0.927 and Sig. (2-tailed) 0.000 at a significance level of 0.01 . A good perception will produce positive results too. This is supported by the results of research by (Ramadhan \& Soenarto, 2015) that students' perceptions of the completeness of practice facilities and infrastructure have a positive and significant effect on student learning achievement. The better an individual's perception of the learning object, the better the individual will be in carrying out the teaching and learning process (Saputra, 2014). The results of the research conducted by the researchers were supported by those conducted by (Nasih \& Sinaga, 2019) which showed that the relationship between students 'basic science process skills and students' perceptions of using e-modules in concave mirror material was very strong. Similar results were also found in research conducted by (Samosir \& Gurning, 2020) on the relationship between students 'perception toward e-module and students' science process skills has a significant correlation so because between the two there is a strong relationship then a good perception will produce good science process skills too. This is supported by research conducted by (Dewi \& Firman, 2019) that the practicum worksheet which contains practicum instructions according to indicators of science process skills can affect students' science process skills. (Maison et al., 2020) that mastery of science process skills are influenced by the type of practicum guidelines used.

The effect of students 'positive perceptions on e-module can be seen at the level of mastery of students' basic science process skills wherefrom the analysis that has been done it is found that $52.7 \%$ are in the very good category for the observation indicator, $47.2 \%$ are in the good category for classification indicators, $50.0 \%$ are in the very good category for measurement indicators, $58.3 \%$ are in the good category for predictive indicators, $55.5 \%$ are in the very good category for communication indicators, and $58.3 \%$ are in the very good category for the conclusion category. The results of data analysis on students' perceptions in using the basic physics practicum guidelines in the form of e-modules gave positive results and students were more interested in using the basic physics practicum guidelines in the form of e-modules. This is in line with the research of (Darmaji et al., 2019) which showed positive results on e-modules which were supported by most of the students who answered positively with various reasons which informed that the use of media could support learning and practicum activities and could motivate students. By using e-module learning can run effectively and flexibly.

\section{Conclusion}

There is a significant relationship between student perceptions of the e-module and students' basic science process skills. Where the relationship is positive, namely a good 
perception of the guidelines used will help in developing students' basic science process skills. This is because a good guide will support the practicum as a forum for developing student science process skills. Suggestions in this study are addressed to researchers and lecturers. It is hoped that the results of this study can be used as a reference for further research. For lecturers, it is hoped that the results of this research can become a reference in the future in designing practical guidelines in the form of an even better e-module.

\section{References}

Ali, R. A., \& Arsyad, M. R. M. (2016). Perspectives of Students' Behavior Towards Mobile Learning (M-learning) in Egypt: an Extension of the UTAUT Model. Engineering, Technology \& Applied Science Research, 6(4), 6. https://doi.org/10.5281/zenodo.60992

Amalia, F., \& Brata, A. H. (2018). Analisis Tingkat Penerimaan Sistem E-Learning menggunakan Blog Gratis sebagai Alternatif Media Pembelajaran pada Guru. Jurnal Teknologi Informasi Dan IImu Komputer, 5(3), 335. https://doi.org/10.25126/jtiik.201853640

Amin, astuti M., Corebima, A. D., Zubaidah, S., \& Mahanal, S. (2019). Analisis Persepsi Mahasiswa Dan Dosen Terhadap Motivasi Belajar Pada Perkuliahan Fisiologi Hewan. Journal of Chemical Information and Modeling, 53(9), 1689-1699. https://doi.org/10.1017/CBO9781107415324.004

Anjani, K., Fatchan, A., \& Amirudin, A. (2016). Pengaruh Pembelajaran Berbasis Turnamen Dan Games Terhadap Motivasi Belajar Siswa. Jurnal Pendidikan - Teori, Penelitian, Dan Pengembangan, 1(9), 1787-1790. https://doi.org/10.17977/jp.v1i9.6812

Asrial, A., Syahrial, S., Maison, M., Kurniawan, D. A., \& Piyana, S. O. (2020). Ethnoconstructivism E-Module To Improve Perception, Interest, and Motivation of Students in Class V Elementary School. JPI (Jurnal Pendidikan Indonesia), 9(1), 30. https://doi.org/10.23887/jpi-undiksha.v9i1.19222

Asrial, Syahrial, Kurniawan, D. A., Chan, F., Septianingsih, R., \& Perdana, R. (2019). Multimedia innovation 4.0 in education: E-modul ethnoconstructivism. Universal Journal of Educational Research, 7(10), 2098-2107. https://doi.org/10.13189/ujer.2019.071007

Astalini, Darmaji, Kurniawan, W., Anwar, K., \& Kurniawan, D. A. (2019). Effectiveness of using e-module and e-assessment. International Journal of Interactive Mobile Technologies, 13(9), 21-39. https://doi.org/10.3991/ijim.v13i09.11016

Astalini, Kurniawan, D. A., Sulistiyo, U., Perdana, R., \& Susbiyanto. (2019). E-assessment motivation in physics subjects for senior high school. International Journal of Online and Biomedical Engineering, 15(11), 4-15. https://doi.org/10.3991/ijoe.v15i11.10843

Bulte, A., Westbroek, H., de Jong, O., \& Pilot, A. (2006). A research approach to designing chemistry education using authentic practices as contexts. International Journal of Science Education, 28(9), 1063-1086. https://doi.org/10.1080/09500690600702520

Coursaris, C., \& Hassanein, K. (2002). Understanding m-commerce: A consumer-centric model Understanding m-Commerce : A Consumer-Centric Model. Quarterly Journal of Electronic Commerce, 3(1), 247-272.

Damyanov, I., \& Tsankov, N. (2018). Mobile apps in daily learning activities. International Journal of Interactive Mobile Technologies, 12(6), 133-140. https://doi.org/10.3991/ijim.v12i6.9659

Darmaji, Astalini, Kurniawan, D. A., Parasdila, H., Iridianti, Susbiyanto, Kuswanto, \& Ikhlas, M. (2019). E-Module based problem solving in basic physics practicum for science process skills. International Journal of Online and Biomedical Engineering, 15(15), 417. https://doi.org/10.3991/ijoe.v15i15.10942

Darmaji, Astalini, Rahayu, A., \& Maison. (2018). Pengembangan Penuntun Praktikum Fisika Berbasis Keterampilan Proses Sains Menggunakan Model Problem Solving. Edusains, 10(1), 83-96.

Darmaji, D., Kurniawan, D. A., Astalini, A., \& Nasih, N. R. (2019). Persepsi Mahasiswa pada Penuntun Praktikum Fisika Dasar II Berbasis Mobile Learning. Jurnal Pendidikan: 
Teori, Penelitian, Dan Pengembangan, 4(4), 516-523.

Darmaji, D., Kurniawan, D. A., Astalini, A., \& Samosir, S. C. (2019). Persepsi Mahasiswa Pendidikan Biologi Dan Pendidikan Kimia Terhadap Penggunaan Buku Panduan Praktikum Fisika Dasar Berbasis Mobile Learning. Edusains, 11(2), 213-220. https://doi.org/10.15408/es.v11i2.11185

Darmaji, D., Kurniawan, D. A., \& Suryani, A. (2019). Effectiveness of Basic Physics II Practicum Guidelines Based On Science Process Skills. JIPF (Jurnal IImu Pendidikan Fisika), 4(1), 1. https://doi.org/10.26737/jipf.v4i1.693

Darmaji, Kurniawan, D. A., Astalini, Kurniawan, W., Anwar, K., \& Lumbantoruan, A. (2019). Students' Perceptions of Electronic's Module in Physics Practicum. 13(2), 288-294. https://doi.org/10.11591/edulearn.v13i2.13005

Darmaji, Kurniawan, D. A., Astalini, Lumbantoruan, A., \& Samosir, S. C. (2019). Mobile learning in higher education for the industrial revolution 4.0: Perception and response of physics practicum. International Journal of Interactive Mobile Technologies, 13(9), 4-20. https://doi.org/10.3991/ijim.v13i09.10948

Dewi, M. P., \& Firman. (2019). Edukatif: Jurnal IImu Pendidikan. Jurnal IImu Pendidikan, 1(3), 294-302.

Foti, M. K., \& Mendez, J. (2014). Mobile Learning: How Students Use Mobile Devices to Support Learning. Journal of Literacy and Technology, 15(3), 58-78.

Haryanto, Asrial, \& Ernawati, M. D. W. (2020). E-worksheet for science processing skills using kvisoft flipbook. International Journal of Online and Biomedical Engineering, 16(3), 46-58. https://doi.org/10.3991/IJOE.V16I03.12381

Ismail, I. Bin, \& M.Idrus, R. (2009). Development of SMS Mobile Technology for M-Learning for Distance Learners. International Journal of Interactive Mobile Technologies (IJIM), 3(2), 55-57. https://doi.org/10.3991/ijim.v3i2.724

Jambulingam, M. (2013). Behavioural intention to adopt mobile technology among tertiary students. World Applied Sciences Journal, 22(9), 1262-1271. https://doi.org/10.5829/idosi.wasj.2013.22.09.2748

Julius Zai, I. (2019). Pengukuran Tingkat Keterampilan Proses Sains Mahasiswa pada Praktikum Gaya Gerak Listrik Induksi di Laboratorium Fisika Dasar Universitas Ahmad Dahlan Yogyakarta. Jupiter: Jurnal Pendidikan Teknik Elektro, 04(1), 1-6.

Maison, Darmaji, Aatalini, Kurniawan, D. A., Haryanto, Kurniawan, W., Suryani, A., Lumbantoruan, A., \& Dewi, U. P. (2020). Science process skill in science program higher education. Universal Journal of Educational Research, 8(2), 652-661. https://doi.org/10.13189/ujer.2020.080238

Margunayasa, I. G., \& Riastini, P. N. (2014). Pengaruh Petunjuk Praktikum Ipa Bermuatan Perubahan Konseptual Terhadap Peningkatan Pemahaman Konsep Ipa Pada Mahasiswa Pgsd. JPI (Jurnal Pendidikan Indonesia), 3(1), 348-358. https://doi.org/10.23887/jpi-undiksha.v3i1.2917

Marhento, G. (2015). Pengaruh Persepsi Siswa Tentang Kompetensi Guru Hasil Belajar IPA ( Studi Pada SMP Se - Kecamatan Periuk Kota Tangerang Banten ). Jurnal Formatif, 1(3), 223-235. https://doi.org/10.30998/formatif.v1i3.73

Misbah, M., Wati, M., Rif'at, M. F., \& Prastika, M. D. (2018). Pengembangan Petunjuk Praktikum Fisika Dasar I Berbasis 5M Untuk Melatih Keterampilan Proses Sains dan Karakter Wasaka. Jurnal Fisika FLUX, 15(1), 26. https://doi.org/10.20527/flux.v15i1.4480

Nasih, N. R., \& Sinaga, S. (2019). Hubungan Persepsi Mahasiswa Pada E-Module Materi. Susunan Artikel Pendidikan, 4(2), 155-162.

Nasih, N. R., Sinaga, S., Studi, P., Fisika, P., Jambi, U., Studi, P., Informatika, T., Asahan, U., Cekung, C., \& Sains, K. P. (2019). Hubungan Persepsi Mahasiswa Pada EModule Materi. 4(2).

Nugraha, U. (2015). Hubungan persepsi, sikap, dan motivasi belajar terhadap hasil belajar pada mahasiswa pendidikan olahraga dan kesehatan Universitas Jambi. Jurnal Cerdas Sifa, 1(1), 37-39.

Nugraheni, A. R. E., \& Dina, D. (2017). Pengaruh Penerapan Pembelajaran E-Learning 
Terhadap Kemandirian Dan Minat Belajar Mahasiswa Pada Mata Kuliah Wawasan Dan Kajian Mipa. Edusains, 9(1). https://doi.org/10.15408/es.v9i1.5458

Oyelere, S. S., Suhonen, J., \& Sutinen, E. (2016). M-learning: A new paradigm of learning ICT in Nigeria. International Journal of Interactive Mobile Technologies, 10(1), 35-44. https://doi.org/10.3991/ijim.v10i1.4872

Pathoni, H., Jufrida, J., Saputri, I., \& Sari, W. (2017). Persepsi Mahasiswa Terhadap E-Modul Pembelajaran Mata Kuliah Fisika Atom Dan Inti. Jurnal Eksakta Pendidikan (Jep), 1(1), 55. https://doi.org/10.24036/jep/vol1-iss1/35

Piliang, F. M. (2019). Pengaruh Model Pembelajaran Pogil terhadap Keterampilan Proses Sains. 8(2), 271-278.

Rahmawati, Handayanto, S. K., \& Dasna, I. W. (2018). Pengaruh Learning Cycle 5E Terhadap Keterampilan Proses Sains Peserta Didik Kelas VIII. Jurnal Pendidikan, 3(3), 286-290.

Ramadhan, A. N., \& Soenarto, S. (2015). Pengaruh Persepsi Siswa Terhadap Faktor-Faktor Yang Mempengaruhi Prestasi Belajar Teori Kejuruan Siswa Smk. Jurnal Pendidikan Vokasi, 5(3), 297-312. https://doi.org/10.21831/jpv.v5i3.6485

Rohman, F., \& Lusiyana, A. (2017). Pengembangan Modul Praktikum Mandiri Sebagai Asesmen Keterampilan Proses Sains dan Keterampilan Sosial Mahasiswa. JIPFRI (Jurnal Inovasi Pendidikan Fisika Dan Riset IImiah), 1(2), 47-56. https://doi.org/10.30599/jipfri.v1i2.115

Rojas-Osorio, M., \& Alvarez-Risco, A. (2019). Intention to use smartphones among Peruvian university students. International Journal of Interactive Mobile Technologies, 13(3), 40-52. https://doi.org/10.3991/ijim.v13i03.9356

Saifuddin, M. F. (2018). E-Learning dalam Persepsi Mahasiswa. Jurnal VARIDIKA, 29(2), 102-109. https://doi.org/10.23917/varidika.v29i2.5637

Salamah, U., \& Mursal. (2017). Meningkatkan Keterampilan Proses Sains Peserta Didik Menggunakan Metode Eksperimen Berbasis Inkuiri Pada Materi Kalor. Jurnal Pendidikan Sains Indonesia (Indonesian Journal of Science Education), 5(1), 59-65.

Samosir, S. C., \& Gurning, L. (2020). Relationship Between the Perception and Skills of Student Basic Science Process in the Use of M-Module in Basic Physics Practicum. Jurnal Pena Sains, 7(1), 8-17. https://doi.org/10.21107/jps.v7i1.6342

Santiani. (2013). Kemampuan Keterampilan Proses Sains Mahasiswa Fisika Stain Palangka Raya Pada Praktikum Fisika Dasar I. Edusains, 1(2), 39-59.

Saputra, D. (2014). Diajukan Sebagai Persyaratan Untuk Menyelesaikan Program Strata Satu Pada Program Studi Pendidikan Teknik Otomotif Jurusan Teknik Otomotif Fakultas Teknik Universitas Negeri Padang. Jurnal Teknik Otomotif Universitas Negeri Padang, 1(1).

Seraj, M., \& Wong, C. Y. (2014). Lecturers and students' perception on learning dijkstra's shortest path algorithm through mobile devices. International Journal of Interactive Mobile Technologies, 8(3), 19-24. https://doi.org/10.3991/ijim.v8i3.3745

Simamora, L. (2014). Pengaruh Persepsi Siswa Tentang Kompetensi Pedagogik Guru Dan Kebiasaan Belajar Siswa. Jurnal Formatif, 4(1), 21-30. https://doi.org/http://dx.doi.org/10.30998/formatif.v4i1.136

Stathopoulou, A., Karabatzaki, Z., Kokkalia, G., Dimitriou, E., Loukeri, P. I., Economou, A., \& Drigas, A. (2018). Mobile assessment procedures for mental health and literacy skills in education. International Journal of Interactive Mobile Technologies, 12(3), 21-37. https://doi.org/10.3991/ijim.v12i3.8038

Sumarti, S. S., Nuswowati, M., \& Kurniawati, E. (2018). Meningkatkan Keterampilan Proses Sains Melalui Pembelajaran Koloid Dengan Lembar Kerja Praktikum Berorientasi Chemo-Entrepreneurship. Phenomenon: Jurnal Pendidikan MIPA, 8(2), 175-184. https://doi.org/10.21580/phen.2018.8.2.2499

Syahrial, Arial, Kurniawan, D. A., \& Piyana, S. O. (2019). E-Modul Etnokontruktivisme: Implementasi Pada Kelas V Sekolah Dasar Ditinjau Dari Persepsi, Minat Dan Motivasi. Jurnal Teknologi Pendidikan, 21(1), 165-177.

Triyono, R. D. F. (2018). Senior High School Students Perception Towards. 3(1), 70-77. 
Vyas, N., \& Nirban, V. S. (2014). Students' Perception on the Effectiveness of Mobile Learning in an Institutional Context. ELT Research Journal, 3(1), 26-36-36.

Wahyudi, W., \& Lestari, I. (2019). Pengaruh Modul Praktikum Optika Berbasis Inkuiri Terhadap Keterampilan Proses Sains dan Sikap Ilmiah Mahasiswa. Jurnal Pendidikan Fisika Dan Keilmuan (JPFK), 5(1), 33-44.

Yunita, A. N., Setiawan, E., Nugroho, H., \& Ramadhan, H. (2018). The relationship between mobile phone usage in classroom and academic achievement in college life. International Journal of Interactive Mobile Technologies, 12(8), 96-103. https://doi.org/10.3991/ijim.v12i8.9530

Yunita, Y., Halim, A., \& Safitri, R. (2019). Meningkatkan Penguasaan Konsep Mahasiswa Dengan Simulasi Physics Eduaction and Technology (PhET). Jurnal Pendidikan Sains Indonesia, 7(1), 16-22. https://doi.org/10.24815/jpsi.v7i1.13492

Ziden, A. A., Rosli, M., Gunasegaran, T., \& Azizan, S. N. (2017). Perceptions and experience in mobile learning via SMS: A case study of distance education students in a Malaysian public university. International Journal of Interactive Mobile Technologies, 11(1), 116-132. https://doi.org/10.3991/ijim.v11i1.6332

Zidoun, Y., El Arroum, F., Talea, M., \& Dehbi, R. (2016). Students' perception about mobile learning in Morocco: Survey analysis. International Journal of Interactive Mobile Technologies, 10(4), 80-84. https://doi.org/10.3991/ijim.v10i4.5947 